\title{
Peranan Sektor Industri Pengolahan dalam Perekonomian Provinsi Sulawesi Utara Analisis Tabel Input-Output
}

\author{
(The Role of Manufacturing Industry Sector in the Economy of Sulawesi Utara Province \\ - An Input-Output Table Analysis)
}

\author{
I Nyoman Pande Suputra \\ Badan Pusat Statistik Provinsi Sulawesi Utara \\ Jl. 17 Agustus, Kota Manado, Provinsi Sulawesi Utara, 95119 \\ E-mail: in.pande@bps.go.id
}

\begin{abstract}
ABSTRAK
Pemerintah berupaya untuk melakukan pemulihan ekonomi masyarakat terdampak Pandemi COVID-19. Sektor industri pengolahan sebagai sektor strategis diharapkan dapat mendukung pemulihan perekonomian. Penelitian ini menganalisis keterkaitan sektor industri pengolahan dengan sektor-sektor lain, mengidentifikasi sektor kunci dari sektor industri pengolahan, serta dampak permintaan akhir dengan menggunakan metode analisis Tabel Input-Output. Data yang digunakan adalah Tabel Input-Output Provinsi Sulawesi Utara Transaksi Domestik 2016 yang dimuktahiran ke 2020 dengan metode RAS. Berdasarkan hasil penelitian, sebagian besar sektor-sektor industri pengolahan memiliki kemampuan mendorong pertumbuhan produksi sektor-sektor lain yang menggunakan inputnya. Sementara itu, hanya sektor industri makanan dan minuman yang peka pada perubahan permintaan akhir. Hal ini menunjukkan sektor industri makanan dan minuman adalah sektor kunci. Dari angka pengganda output yang dihasilkan, kenaikan 1 rupiah permintaan akhir sektor industri makanan dan minuman akan menyebabkan kenaikan output seluruh sektor sebesar 1,6754 rupiah. Kenaikan permintaan akhir pada sektor ini berdampak pada peningkatan output dan NTB yang lebih besar.
\end{abstract}

Kata kunci: industri pengolahan, permintaan akhir, tabel input-output

\begin{abstract}
Government tries to restore the economy affected by COVID-19 pandemic. Manufacturing sector is expected to support economic recovery. This study analyzes the linkage of the manufacturing industry sector with others, identifies leading sectors, and impact of final demand using the Input-Output Table analysis. The data used is the Input-Output Table of Sulawesi Utara Domestic Transactions 2016 which was updated to 2020 using the RAS method. Based on the results, most of the manufacturing industry can encourage production growth in others that use its inputs. Meanwhile, only FnB industry is sensitive to changes in final demand. This shows that FnB industry is a leading sector. From the resulting output multiplier, an increase of 1 rupiah in final demand for FnB industry will cause an increase in the output of all sectors by 1.6754 rupiah. Final demand increased in this sector has an impact on a greater increase in output and GVA.
\end{abstract}

Keywords: manufacturing industry, final demand, input-output table

\section{PENDAHULUAN}

Provinsi Sulawesi Utara pada tahun 2020, mengalami kontraksi pertumbuhan ekonomi sebesar 0,99 persen (Badan Pusat Statistik Provinsi Sulawesi Utara, 2021). Hal ini merupakan salah satu dampak dari diberlakukannya pembatasan kegiatan masyarakat karena pandemi COVID-19. Pemerintah berusaha untuk melakukan berbagai program dalam rangka pemulihan ekonomi. Program percepatan pemulihan ekonomi dan sosial Pemerintah Provinsi Sulawesi Utara, berfokus pada sektor-sektor strategis perekonomian. Peningkatan sektor-sektor strategis ini diharapkan dapat berdampak pada peningkatan pertumbuhan ekonomi dan penyerapan tenaga kerja. Dikutip dari bisnis.com, Gubernur Sulawesi Utara menyampaikan untuk mempercepat pemulihan ketahanan ekonomi dilakukan kebijakan mengembangkan pariwisata dan industri dengan basis sumber daya lokal.

Sektor industri pengolahan memiliki peran relatif stabil dari tahun ke tahun terhadap perekonomian Provinsi Sulawesi Utara (Amin, Rumagit, \& Katiandagho, 2015). Pengembangan industri yang dilakukan pada Kawasan Ekonomi Khusus (KEK) di Kota Bitung, Sulawesi Utara, dapat menimbulkan multiplier effect pada peningkatan pertumbuhan ekonomi Provinsi Sulawesi Utara (Makalew, Masinambouw, \& Walewangko, 2017). Hasil penelitian ini menunjukkan adanya pengembangan KEK meningkatkan penyerapan tenaga kerja 
serta peningkatan sumbangan industri menengah pada pertumbuhan ekonomi. Pada perekonomian Kota Bitung, Sulawesi Utara, sektor industri pengolahan menjadi salah satu sektor basis, yang dapat menjadi penggerak utama perekonomian Provinsi Sulawesi Utara (Lapong, Kindangen, \& Walewangko, 2018).

Pada tahun 2020, sektor industri pengolahan memberikan sumbangan sebesar 9,56 persen terhadap pertumbuhan ekonomi Provinsi Sulawesi Utara (Badan Pusat Statistik Provinsi Sulawesi Utara, 2021). Hal ini menjadikan sektor industri pengolahan sebagai sektor penyumbang pertumbuhan terbesar keempat setelah Pertanian, Kehutanan dan Perikanan; Konstruksi; serta Perdagangan Besar dan Eceran, Reparasi Mobil dan Sepeda Motor. Pertumbuhan ekonomi industri pengolahan di Provinsi Sulawesi Utara tumbuh sebesar 4,41 persen. Dari empat sektor yang memiliki sumbangan terbesar pada pertumbuhan ekonomi Provinsi Sulawesi Utara, sektor industri pengolahan menjadi sektor dengan pertumbuhan tertinggi. Gambar 1. menunjukkan, selama periode 2015 sampai dengan 2020, walaupun mengalami penurunan di Tahun 2018 dan 2019, industri pengolahan di Provinsi Sulawesi Utara dapat tumbuh positif pada saat kondisi Pandemi COVID-19. Pertumbuhan ini tergolong tinggi jika dibandingkan dengan pertumbuhan ekonomi keseluruhan sektor yang mengalami kontraksi. Selain itu, penyerapan tenaga kerja di sektor industri pengolahan cukup tinggi. Persentase penduduk angkatan kerja yang bekerja di sektor industri pengolahan sebesar 8,58 persen.

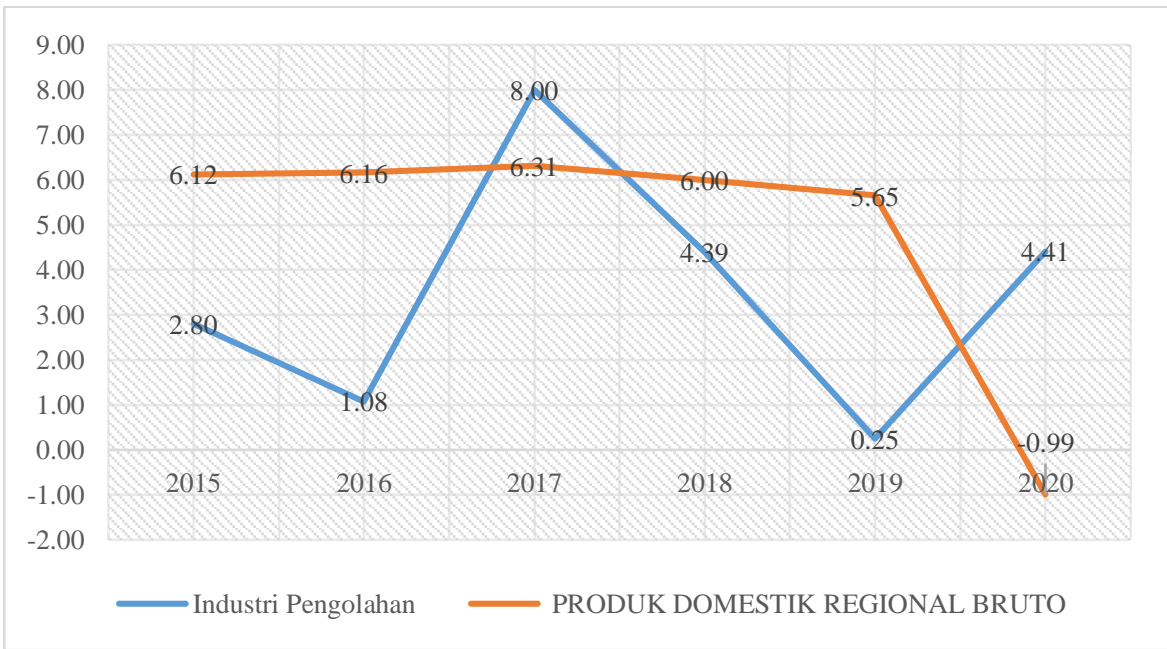

Sumber: www.sulut.bps.go.id,diolah

Gambar 1. Pertumbuhan Ekonomi Industri Pengolahan dan Seluruh Sektor Provinsi Sulawesi Utara, Periode Tahun 2015 sampai dengan 2020.

Sektor Industri Pengolahan terindikasi dapat menjadi pendukung dalam pembangunan sektor-sektor lainnya di Provinsi Sulawesi Utara. Peran sektor industri pengolahan ini tidak hanya ditinjau dari kontribusi terhadap pertumbuhan ekonomi secara keseluruhan, namun penting diketahui bagaimana pengaruh dari sektor ini terhadap sektor-sektor lain dalam perekonomian. Selain itu, pengaruh dari permintaan akhir atau pengeluaran dalam perekonomian berkaitan erat dengan sumbangan sektor industri pengolahan terhadap perekonomian Provinsi Sulawesi Utara. Untuk dapat menggambarkan dan menganalisis hal ini diperlukan alat analisis yang komprehensif dan terintegrasi. Untuk mengkaji keterkaitan antara sisi produksi pada perekonomian denga permintaan akhir, diperlukan kerangka data ekonomi yang utuh dan terintegrasi (Yusa, 2019).

Analisis Tabel Input-Output adalah alat analisis suatu perekonomian secara komprehensif, karena dapat menggambarkan keterkaitan antar sektor ekonomi pada suatu wilayah secara menyeluruh (Masli \& Rusmalia, 2010). Tabel Input-Output adalah uraian statistik berbentuk matriks yang di dalamnya disajikan informasi tentang transaksi barang dan jasa serta saling keterkaitan antar sektor kegiatan ekonomi dalam suatu wilayah, pada suatu periode waktu (Badan Pusat Statistik, 2008). Penelitian mengenai peran sektor industri terhadap sektor-sektor lainnya pada perekonomian dengan menggunakan Tabel Input-Output, telah dilakukan oleh peneliti sebelumnya. Penelitian mengenai peran sektor industri pengolahan dalam perekonomian Indonesia pada tahun 2010-2016 menyimpulkan pembangunan sektor industri pengolahan dapat meningkatkan pembangunan sektor-sektor lainnya dan akan meningkatan perekonomian secara keseluruhan (Rahmah \& Widodo, 2019). Sementara itu, analisis tabel input-output untuk melihat peranan sektor industri pengolahan terhadap perekonomian Jawa Timur pada tahun 2007-2011, menunjukkan sektor industri dapat menjadi penggerak bagi sektor lainnya (Margalita, Badjuri, \& Komariyah, 2015). Berdasarkan hasil penelitian tersebut, sektor industri pengolahan mempunyai peran yang besar, dilihat dari daya penyebaran maupun derajat kepekaan yang dihasilkan. Selanjutnya, hasil penelitian mengenai analisis peranan sektor industri terhadap 
perekonomian Jawa Tengah tahun 2000 dan 2004, sektor kunci yang diidentifikasi perlu mendapatkan perhatian lebih, karena sektor-sektor ini mempunyai peranan penting (Purnomo \& Istiqomah, 2008).

Penelitian ini akan menentukan sektor kunci (leading sector) sebagai sektor unggulan dari sektor-sektor industri pengolahan di Provinsi Sulawesi Utara tahun 2020. Selain itu, penelitian ini akan menganalisis keterkaitan sektor industri pengolahan dengan sektor-sektor lain serta dampak permintaan akhir pada sektor industri pengolahan dalam perekonomian Provinsi Sulawesi Utara, dengan menggunakan pendekatan analisis Tabel Input-Output. Hasil dari analisis diharapkan dapat menjadi acuan menentukan program kebijakan yang perlu dilakukan untuk mendorong pemulihan ekonomi masyarakat.

\section{METODE}

Metode dalam penelitian ini adalah menggunakan perangkat analisis Tabel Input-Output. Metode ini dibangun oleh Profesor Wassily Leontif pada 1930 (Miller \& Blair, 2009). Tabel Input-Ouput dapat menggambarkan transaksi barang dan jasa antar sektor dalam suatu perekonomian. Menurut (Badan Pusat Statistik, 2021). Tabel Input-Ouput memiliki asumsi antara lain: (1) Keseragaman (Homogenity), ini berarti tiap-tiap sektor ekonomi hanya memproduksi satu jenis barang dan jasa dengan susunan input yang seragam dan tidak ada substitusi otomatis terhadap input dari output sektor yang berbeda; (2) Kesebandingan (Proportionality), artinya hubungan antara input dan output setiap sektor mengikuti prinsip fungsi linier; (3) Penjumlahan (Additivity) artinya total efek dari kegiatan produksi di berbagai sektor merupakan penjumlahan dari efek kegiatan masing-masing sektor yang terpisah. Dengan asumsi tersebut, keterbatasan Tabel InputOutput antara lain: karena rasio input-output tetap konstan sepanjang periode analisis, produsen tak dapat menyesuaikan perubahan-perubahan inputnya atau mengubah proses produksi (Badan Pusat Statistik, 2008). Tabel input-ouput terdiri dari empat kuadran antara lain: Kuadran 1, memuat arus transaksi antar sektor; Kuadran 2, merupakan permintaan akhir dan output total yang dirinci menurut sektor; Kuadran 3, memuat input primer yang digunakan maupun ouput yang dihasilkan masing-masing sektor; Kuadran 4, berisi jumlah input primer yang juga merupakan permintaan akhir dan output total.

Penelitian ini menggunakan data sekunder dari Badan Pusat Statistik. Data yang digunakan antara lain Tabel Input-Output Provinsi Sulawesi Utara Transaksi Domestik Atas Dasar Harga Produsen Menurut 52 Kategori Lapangan Usaha tahun 2016, serta Produk Domestik Regional Bruto (PDRB) Provinsi Sulawesi Utara menurut Lapangan Usaha dan Pengeluaran Tahun 2020. Tahapan analisis data yang dilakukan adalah: (1) melakukan agregasi 52 kategori menjadi 29 kategori lapangan usaha, yang di dalamnya dirinci sektorsektor industri pengolahan. Sektor industri pengolahan yang dirinci adalah sebanyak 13 sektor; (2) melakukan pemuktahiran Tabel Input-Output Provinsi Sulawesi Utara Tahun 2016 menjadi Tahun 2020 berdasarkan PDRB Provinsi Sulawesi Utara menurut Lapangan Usaha dan Pengeluaran Tahun 2020 dengan metode RAS. Metode RAS adalah metode matematik semi survei yang diperkenalkan oleh Richard Stone (Miller \& Blair, 2009). (3) menghitung Indeks Daya Penyebaran (IDP) dan Indeks Derajat Kepekaan (IDK) yang bertujuan melihat keterkaitan sektor industri pengolahan dengan sektor-sektor lainnya serta menghitung angka pengganda output dan dampak output. Angka penganda output adalah nilai total dari output yang dihasilkan oleh perekonomian akibat adanya perubahan permintaan akhir suatu sektor (Widyawati, 2017).

\section{HASIL DAN PEMBAHASAN}

Kerjasama yang baik antar sektor dalam suatu perekonomian diperlukan untuk mencapai pembangunan ekonomi (Rahmah \& Widodo, 2019). Indeks Daya Penyebaran (IDP) yaitu indeks yang menggambarkan dampak dari perubahan permintaan akhir suatu sektor terhadap output seluruh sektor. Sementara itu, Indeks Derajat Kepekaan (IDK) adalah indeks yang menggambarkan dampak yang terjadi terhadap output suatu sektor karena adanya perubahan permintaan akhir pada masing- masing sektor perekonomian. Berdasarkan hasil penelitian, Tabel 1. menggambarkan sebagian besar sektor- sektor industri pengolahan memiliki IDP lebih dari satu. Hal ini menunjukkan daya penyebaran sektor industri pengolahan berada di atas daya penyebaran seluruh sektor lainnya, yang berarti sektor ini memiliki kemampuan yang cukup baik untuk mendorong pertumbuhan produksi sektor-sektor lain yang menggunakan input sektor industri pengolahan. Tiga sektor industri pengolahan dengan IDP lebih dari satu antara lain industri logam dasar; industri makanan dan minuman; serta industri karet, barang dari karet dan plastik. Sementara itu, IDK yang memiliki nilai lebih dari satu hanya pada sektor industri makanan dan minuman. Hal ini menunjukkan, hanya sektor ini yang peka jika terdapat perubahan permintaan akhir pada masing-masing sektor perekonomian. 
Tabel 1. Indeks Daya Penyebaran (IDP) dan Indeks Derajat Kepekaan (IDK) menurut Sektor Industri Pengolahan di Provinsi Sulawesi Utara, Tahun 2020.

\begin{tabular}{clcc}
\hline Kode & \multicolumn{1}{c}{ Sektor Industri Pengolahan } & IDP & IDK \\
\hline I-1 & Industri Makanan dan Minuman & 1,5765 & 1,3734 \\
I-2 & Industri Tekstil dan Pakaian Jadi & 1,2896 & 0,1161 \\
I-3 & Industri Kulit, Barang dari Kulit dan Alas Kaki & 0,9776 & 0,0016 \\
I-4 & Industri Kayu, Barang dari Kayu dan Gabus dan Barang Anyaman dari Bambu, Rotan & 0,9792 & 0,3252 \\
& dan Sejenisnya & & \\
I-5 & Industri Kertas dan Barang dari Kertas, Percetakan dan Reproduksi Media Rekaman & 0,9641 & 0,4355 \\
I-6 & Industri Kimia, Farmasi dan Obat Tradisional & 1,1746 & 0,2755 \\
I-7 & Industri Karet, Barang dari Karet dan Plastik & 1,7021 & 0,0375 \\
I-8 & Industri Barang Galian bukan Logam & 1,2405 & 0,0013 \\
I-9 & Industri Logam Dasar & 1,6558 & 0,1376 \\
I-10 & Industri Barang dari Logam, Komputer, Barang Elektronik, Optik dan Peralatan Listrik & 0,6465 & 0,1905 \\
I-11 & Industri Alat Angkutan & 1,0266 & 0,0677 \\
I-12 & Industri Furnitur & 0,8610 & 0,0710 \\
I-13 & Industri Pengolahan Lainnya, Jasa Reparasi dan Pemasangan Mesin dan Peralatan & 0,9779 & 0,1335 \\
\hline
\end{tabular}

Sektor industri makanan dan minuman menjadi sektor kunci (leading sector) karena mempunyai IDP dan IDK di atas satu. Ini berarti, sektor industri makanan dan minuman merupakan sektor yang mampu mendorong pertumbuhan sektor-sektor lain sekaligus peka terhadap perubahan permintaan. Peningkatan pada sektor industri makanan dan minuman dapat memberikan efek stimulus untuk sektor-sektor lain yang kemudian dapat meningkatkan perekonomian. Berdasarkan tabel input- output yang disusun, output dari sektor industri makanan dan minuman digunakan oleh seluruh sektor dalam perekonomian. Sektor makanan dan minuman sendiri, sektor transportasi dan pergudangan dan sektor jasa kesehatan dan kegiatan sosial menjadi tiga sektor terbesar yang menggunakan output dari sektor industri makanan dan minuman sebagai input antara. Besarannya masing- masing adalah 31,52 persen, 17,24 persen, dan 9,34 persen. Industri makanan dan minuman peka terhadap perubahan sektor lainnya karena membutuhkan output dari seluruh sektor dalam perekonomian. Tiga sektor terbesar yang digunakan outputnya oleh sektor industri pengolahan adalah sektor pertanian, kehutanan, dan perikanan; sektor perdagangan besar dan eceran, reparasi mobil dan sepeda motor; serta sektor industri makanan dan minuman itu sendiri. Besarannya masing- masing adalah 62,94 persen, 11,85 persen, dan 7,75 persen.

Tabel 2. Angka Pengganda Output menurut Sektor Industri Pengolahan di Provinsi Sulawesi Utara, Tahun 2020.

\begin{tabular}{rlc}
\hline Kode & Sektor Industri Pengolahan & Pengganda Output \\
\hline I-1 & Industri Makanan dan Minuman & 1,6754 \\
I-2 & Industri Tekstil dan Pakaian Jadi & 1,6291 \\
I-3 & Industri Kulit, Barang dari Kulit dan Alas Kaki & 1,5201 \\
I-4 & Industri Kayu, Barang dari Kayu dan Gabus dan Barang Anyaman dari Bambu, & 1,4827 \\
& Rotan dan Sejenisnya \\
I-5 & Industri Kertas dan Barang dari Kertas, Percetakan dan Reproduksi Media & 1,4825 \\
I-6 & Rekaman & \\
I-7 & Industri Kimia, Farmasi dan Obat Tradisional & 1,5945 \\
I-8 & Industri Karet, Barang dari Karet dan Plastik & 1,9043 \\
I-9 & Industri Barang Galian bukan Logam & 1,6615 \\
I-10 & Industri Logam Dasar & 1,6473 \\
& Listrik & 1,3194 \\
I-11 & Industri Alat Angkutan & 1,5062 \\
I-12 & Industri Furnitur & 1,4188 \\
I-13 & Industri Pengolahan Lainnya, Jasa Reparasi dan Pemasangan Mesin dan & 1,4883 \\
& Peralatan & \\
\hline
\end{tabular}


Angka pengganda output dari seluruh sektor industri pengolahan bernilai lebih dari satu seperti data pada Tabel 2. Hal ini menunjukkan sektor industri pengolahan dapat memberikan peningkatan total seluruh output perekonomian yang lebih besar sebagai dampak dari kenaikan permintaan akhir. Sektor industri karet, barang dari karet dan plastik mempunyai angka pengganda output tertinggi dibandingkan dengan sektor-sektor industri pengolahan lainnya. Setiap kenaikan 1 rupiah permintaan akhir sektor industri karet, barang dari karet dan plastik akan menyebabkan kenaikan output seluruh sektor sebesar 1,9043 rupiah. Selain itu, sektor industri makanan dan minuman menjadi sektor industri pengolahan berikutnya yang memiliki angka pengganda lebih dari 1. Setiap kenaikan 1 rupiah permintaan akhir sektor industri makanan dan minuman akan menyebabkan kenaikan output seluruh sektor sebesar 1,6754 rupiah.

Hasil pada Tabel 3. menunjukkan komponen permintaan akhir membentuk output dari sektor-sektor industri pengolahan pada tahun 2020. Sektor industri makanan dan minuman menjadi sektor dengan output terbesar yang terbentuk. Output dari sektor ini terbentuk karena adanya permintaan akhir konsumsi rumah tangga sebesar 9,23 trilliun rupiah dan Pembentukan Modal Teta Bruto (PMTB) atau investasi adalah sebesar 7,532 triliun rupiah. Selanjutnya, output sektor ini terbentuk karena adanya konsumsi pemerintah, pengeluaran Lembaga Non-Profit yang Melayani Rumah Tangga (LNPRT), dan ekspor adalah masing- masing sebesar 3,612 triliun rupiah, 464,36 miliar rupiah, dan 480,45 miliar rupiah. Selanjutnya, pada sektor industri barang galian bukan logam, output yang terbentuk karena adanya permintaan akhir konsumsi rumah tangga sebesar 663,79 miliar rupiah, konsumsi LNPRT sebesar 33,39 miliar rupiah, konsumsi pemerintah sebesar 259,81 miliar rupiah, investasi sebesar 541,70 miliar rupiah, dan ekspor sebesar 34,55 miliar rupiah. Kedua sektor ini menjadi sektor dengan output terbesar dari sektor-sektor industri pengolahan yang dipengaruhi oleh komponen permintaan akhir. Output industri barang galian bukan logam tinggi karena adanya PMTB karena industri ini menjadi salah satu bahan baku peralatan kesehatan dan laboratorium. Peralatan ini permintaan dan penggunaanya meningkat ditengah pandemi. Selain dua sektor tersebut, sektor industri kimia, farmasi dan obat memiliki output yang terbentuk cukup tinggi karena konsumsi rumah tangga yaitu 160,35 miliar rupiah. Hal ini dapat terjadi karena, pada saat pandemi COVID-19 terjadi peningkatan konsumsi obat dan vitamin untuk meningkatkan daya tahan tubuh.

Tabel 3. Output Sektor Industri Pengolahan yang Dipengaruhi oleh Masing-Masing Komponen Permintaan Akhir di Provinsi Sulawesi Utara, Tahun 2020 (Miliar Rupiah).

\begin{tabular}{|c|c|c|c|c|c|c|}
\hline Kode & Sektor Industri Pengolahan & $\begin{array}{l}\text { Konsumsi } \\
\text { Rumah } \\
\text { Tangga }\end{array}$ & $\begin{array}{l}\text { Konsumsi } \\
\text { LNPRT }\end{array}$ & $\begin{array}{c}\text { Konsumsi } \\
\text { Pemerintah }\end{array}$ & PMTB & Ekspor \\
\hline $\mathrm{I}-1$ & Industri Makanan dan Minuman & $9.230,04$ & 464,36 & $3.612,70$ & $7.532,34$ & 480,45 \\
\hline $\mathrm{I}-2$ & Industri Tekstil dan Pakaian Jadi & 56,73 & 2,85 & 22,20 & 46,29 & 2,95 \\
\hline $\mathrm{I}-3$ & $\begin{array}{l}\text { Industri Kulit, Barang dari Kulit dan Alas } \\
\text { Kaki }\end{array}$ & 1,76 & 0,09 & 0,69 & 1,44 & 0,09 \\
\hline $\mathrm{I}-4$ & $\begin{array}{l}\text { Industri Kayu, Barang dari Kayu dan Gabus } \\
\text { dan Barang Anyaman dari Bambu, Rotan dan } \\
\text { Sejenisnya }\end{array}$ & 96,28 & 4,84 & 37,68 & 78,57 & 5,01 \\
\hline $\mathrm{I}-5$ & $\begin{array}{l}\text { Industri Kertas dan Barang dari Kertas, } \\
\text { Percetakan dan Reproduksi Media Rekaman }\end{array}$ & 271,14 & 13,64 & 106,13 & 221,27 & 14,11 \\
\hline $\mathrm{I}-6$ & $\begin{array}{l}\text { Industri Kimia, Farmasi dan Obat } \\
\text { Tradisional }\end{array}$ & 160,35 & 8,07 & 62,76 & 130,86 & 8,35 \\
\hline $\mathrm{I}-7$ & Industri Karet, Barang dari Karet dan Plastik & 12,19 & 0,61 & 4,77 & 9,95 & 0,63 \\
\hline $\mathrm{I}-8$ & Industri Barang Galian bukan Logam & 663,79 & 33,39 & 259,81 & 541,70 & 34,55 \\
\hline $\mathrm{I}-9$ & Industri Logam Dasar & 137,91 & 6,94 & 53,98 & 112,55 & 7,18 \\
\hline $\mathrm{I}-10$ & $\begin{array}{l}\text { Industri Barang dari Logam, Komputer, } \\
\text { Barang Elektronik, Optik dan Peralatan } \\
\text { Listrik }\end{array}$ & 233,07 & 11,73 & 91,22 & 190,20 & 12,13 \\
\hline $\mathrm{I}-11$ & Industri Alat Angkutan & 58,07 & 2,92 & 22,73 & 47,39 & 3,02 \\
\hline $\mathrm{I}-12$ & Industri Furnitur & 62,30 & 3,13 & 24,39 & 50,84 & 3,24 \\
\hline $\mathrm{I}-13$ & $\begin{array}{l}\text { Industri Pengolahan Lainnya, Jasa Reparasi } \\
\text { dan Pemasangan Mesin dan Peralatan }\end{array}$ & 82,63 & 4,16 & 32,34 & 67,43 & 4,30 \\
\hline
\end{tabular}


Tabel 4. Nilai Tambah Bruto Sektor Industri Pengolahan yang Dipengaruhi oleh Masing-Masing Komponen Permintaan Akhir di Provinsi Sulawesi Utara, Tahun 2020 (Miliar Rupiah).

\begin{tabular}{|c|c|c|c|c|c|c|}
\hline Kode & Sektor Industri Pengolahan & $\begin{array}{l}\text { Konsumsi } \\
\text { Rumah } \\
\text { Tangga }\end{array}$ & $\begin{array}{l}\text { Konsumsi } \\
\text { LNPRT }\end{array}$ & $\begin{array}{l}\text { Konsumsi } \\
\text { Pemerintah }\end{array}$ & PMTB & Ekspor \\
\hline $\mathrm{I}-1$ & Industri Makanan dan Minuman & $4.485,23$ & 225,65 & $1.755,55$ & $3.660,25$ & 0,70 \\
\hline I-2 & Industri Tekstil dan Pakaian Jadi & 32,87 & 1,65 & 12,87 & 26,83 & 0,01 \\
\hline $\mathrm{I}-3$ & $\begin{array}{l}\text { Industri Kulit, Barang dari Kulit dan Alas } \\
\text { Kaki }\end{array}$ & 1,20 & 0,06 & 0,47 & 0,98 & 0,00 \\
\hline I-4 & $\begin{array}{l}\text { Industri Kayu, Barang dari Kayu dan Gabus } \\
\text { dan Barang Anyaman dari Bambu, Rotan } \\
\text { dan Sejenisnya }\end{array}$ & 65,54 & 3,30 & 25,65 & 53,48 & 0,01 \\
\hline $\mathrm{I}-5$ & $\begin{array}{l}\text { Industri Kertas dan Barang dari Kertas, } \\
\text { Percetakan dan Reproduksi Media Rekaman }\end{array}$ & 185,90 & 9,35 & 72,76 & 151,70 & 0,03 \\
\hline I-6 & $\begin{array}{l}\text { Industri Kimia, Farmasi dan Obat } \\
\text { Tradisional }\end{array}$ & 98,93 & 4,98 & 38,72 & 80,74 & 0,02 \\
\hline $\mathrm{I}-7$ & $\begin{array}{l}\text { Industri Karet, Barang dari Karet dan } \\
\text { Plastik }\end{array}$ & 5,42 & 0,27 & 2,12 & 4,43 & 0,00 \\
\hline I-8 & Industri Barang Galian bukan Logam & 395,29 & 19,89 & 154,72 & 322,58 & 0,06 \\
\hline I-9 & Industri Logam Dasar & 63,45 & 3,19 & 24,84 & 51,78 & 0,01 \\
\hline $\mathrm{I}-10$ & $\begin{array}{l}\text { Industri Barang dari Logam, Komputer, } \\
\text { Barang Elektronik, Optik dan Peralatan } \\
\text { Listrik }\end{array}$ & 183,94 & 9,25 & 71,99 & 150,10 & 0,03 \\
\hline $\mathrm{I}-11$ & Industri Alat Angkutan & 38,63 & 1,94 & 15,12 & 31,52 & 0,01 \\
\hline $\mathrm{I}-12$ & Industri Furnitur & 44,81 & 2,25 & 17,54 & 36,57 & 0,01 \\
\hline $\mathrm{I}-13$ & $\begin{array}{l}\text { Industri Pengolahan Lainnya, Jasa Reparasi } \\
\text { dan Pemasangan Mesin dan Peralatan }\end{array}$ & 56,28 & 2,83 & 22,03 & 45,93 & 0,01 \\
\hline
\end{tabular}

Hasil pada Tabel 4. menunjukkan komponen permintaan akhir membentuk nilai tambah bruto (NTB) dari sektor-sektor industri pengolahan pada tahun 2020. Sektor industri makanan dan minuman menjadi sektor dengan NTB terbesar yang terbentuk. NTB dari sektor ini terbentuk karena adanya permintaan akhir konsumsi rumah tangga sebesar 4,485 trilliun rupiah dan investasi sebesar 3,66 triliun rupiah. Sementara itu, output sektor ini terbentuk karena adanya konsumsi pemerintah, pengeluaran LNPRT, dan ekspor adalah masingmasing sebesar 1,755 triliun rupiah, 225,65 miliar rupiah, dan 700 juta rupiah. Pada sektor industri makanan dan minuman pada kondisi pandemi COVID-19 justru mengalami peningkatan. Hal ini dikarenakan banyak masyarakat yang memulai usaha makanan dan minuman berskala mikro dan kecil sebagai upaya untuk menambah pendapatan. Selanjutnya, pada sektor industri barang galian bukan logam, NTB yang terbentuk dari sektor ini karena adanya permintaan akhir konsumsi rumah tangga sebesar 395,29 miliar rupiah, konsumsi LNPRT sebesar 19,89 miliar rupiah, konsumsi pemerintah sebesar 154,72 miliar rupiah, investasi sebesar 322,58 miliar rupiah, dan ekspor sebesar 60 juta rupiah. Kedua sektor ini menjadi sektor dengan output terbesar dari sektor-sektor industri pengolahan yang dipengaruhi oleh komponen permintaan akhir. Selain itu, kedua sektor ini menjadi dua sektor dengan NTB terbesar. NTB yang terbentuk ini kemudian akan menjadi sumber pendapatan masyarakat.

\section{KESIMPULAN}

Berdasarkan analisis tabel input-output yang dilakukan, sebagian besar sektor- sektor industri pengolahan memiliki daya penyebaran di atas daya penyebaran seluruh sektor lainnya, yang berarti sektor ini memiliki kemampuan yang cukup baik untuk mendorong pertumbuhan produksi sektor-sektor lain yang menggunakan input sektor industri pengolahan. Sementara itu, hanya sektor industri makanan dan minuman yang peka jika terdapat perubahan permintaan akhir pada masing-masing sektor perekonomian. Hal ini menjadikan sektor industri makanan dan minuman menjadi sektor dengan keterkaitan paling kuat. Sektor ini adalah sektor kunci (leading sector) karena mampu mendorong sektor-sektor lain sekaligus peka terhadap perubahan permintaan. Selanjutnya, angka pengganda output dari seluruh sektor industri pengolahan menunjukkan sektor industri pengolahan dapat memberikan peningkatan total seluruh output perekonomian yang lebih besar sebagai dampak dari kenaikan permintaan akhir. Sektor industri makanan dan minuman menjadi sektor dengan output dan NTB terbesar yang terbentuk, akibat adanya kenaikan komponen permintaan akhir. 
Kebijakan strategis untuk meningkatkan produksi sektor industri pengolahan khususnya industri makanan dan minuman perlu menjadi perhatian. Pengembangan sektor industri makanan dan minuman ini terutama pada industri mikro dan kecil dapat berdampak langsung pada peningkatan pendapatan dan daya beli masyarakat. Selain itu, pengembangan pada industri berskala sedang dan besar juga akan dapat menyerap tenaga kerja serta bahan baku lebih banyak. Dengan kontribusi dari sektor industri pengolahan ini diharapkan dapat terjadi pemulihan perekonomian masyarakat.

\section{DAFTAR PUSTAKA}

Amin, A. A., Rumagit, G. A., \& Katiandagho, T. M. (2015). Peranan Sektor Industri Pengolahan terhadap Perekonomian dan Penyerapan Tenaga Kerja di Provinsi Sulawesi Utara. Cocos Vol 6 No 8.

Badan Pusat Statistik. (2008). Kerangka Teori dan Analisis Tabel Input-Output. Jakarta: Badan Pusat Statistik. Badan Pusat Statistik. (2008). Teknik Penyusunan Tabel Input-Output. Jakarta: Badan Pusat Statistik.

Badan Pusat Statistik. (2021). Tabel Input-Output Indonesia 2016. Jakarta: Badan Pusat Statistik.

Badan Pusat Statistik Provinsi Sulawesi Utara. (2021). Produk Domestik Regional Bruto Provinsi Sulawesi Utara menurut Lapangan Usaha 2016-2020. Manado: Badan Pusat Statistik Provinsi Sulawesi Utara.

Badan Pusat Statistik Provinsi Sulawesi Utara. (2021, Mei 31). Tabel Input-Output Provinsi Sulawesi Utara Transaksi Domestik Atas Dasar Harga Produsen Menurut 52 Industri, 2016 (Juta Rupiah). https://sulut.bps.go.id/statictable/2021/05/31/187/tabel-input-output-provinsi-sulawesi-utara-transaksidomestik-atas-dasar-harga-produsen-menurut-52-industri-2016-juta-rupiah-.html [14 Juli 2021]

Badan Pusat Statitsik Provinsi Sulawesi Utara. (2021). Produk Domestik Regional Bruto Provinsi Sulawesi Utara menurut Pengeluaran 2016-2020. Manado: Badan Pusat Statitsik Provinsi Sulawesi Utara.

Bisnis.com. (5 Januari 2021). Program Pemulihan Ekonomi jadi Prioritas Pemerintah Sulut Tahun 2021 https://sulawesi.bisnis.com/read/20210105/539/1338766/program-pemulihan-ekonomi-jadi-prioritaspemerintah-sulut-tahun-2021 [14 Juli 2021]

Lapong, P. R., Kindangen, P., \& Walewangko, E. N. (2018). Analisis Peranan Sektor Basis dan Non Basis dalam Penyerapan Tenaga Kerja (Studi Kasus Empat Kota di Sulawesi Utara). Jurnal Pembangunan Ekonomi dan Keuangan Daerah Vol 19 No 4, 92-105.

Makalew, V. N., Masinambouw, V. A., \& Walewangko, E. N. (2017). Analisis Kontribusi Kawasan Ekonomi Khusus (KEK) Terhadap Struktur Perekonomian Sulawesi Utara. Jurnal Pembangunan Ekonomi dan Keuangan Daerah Volume 18 No 5, 1-13.

Margalita, W., Badjuri, \& Komariyah, S. (2015). Peranan Sektor Industri Pengolahan terhadap Perekonomian Jawa Timur Tahun 2007-2011 (Pendekatan Input-Output Analysis). Artikel Ilmiah Remaja.

Masli, L., \& Rusmalia, E. (2010). Analisis Input-Output dalam Perencanaan Ekonomi Vol. 2 No. 1. Jurnal Sains Manajemen dan Akuntansi, 60-65.

Miller, R. E., \& Blair, P. D. (2009). Input-Output Analysis - Foundations and Extensions. New York: Cambridge University Press.

Purnomo, D., \& Istiqomah, D. (2008). Analisis Peranan Sektor Industri terhadap Perekonomian Jawa Tengah Tahun 2000 dan Tahun 2004 (Analisis Input Output). Jurnal Ekonomi Pembangunan Vol.9 No.2, 137155.

Rahmah, A. N., \& Widodo, S. (2019). Peranan Sektor Industri Pengolahan dalam Perekonomian di Indonesia dengan Pendekatan Input-Output Tahun 2010-2016. Economie Vol. 01, No. 01, 14-37.

Widyawati, R. F. (2017). Analisis Keterkaitan Sektor Pertanian dan Pengaruhnya terhadap Perekonomian Indonesia (Analisis Input Output). Jurnal Economia, Volume 13, Nomor 1, 14-27.

Yusa, I. G. (2019). Analisis Keterkaitan dan Dampak Permintaan Akhir terhadap Sektor Produksi di Indonesia. Prosiding Seminar Nasional Official Statistics 2019: Pengembangan Official Statistics dalam mendukung Implementasi SDG 's. doi:https://doi.org/10.34123/semnasoffstat.v2019i1.172 